\title{
TNF down-regulation of receptor tyrosine kinase- dependent mitogenic signal pathways as an important step in cytostasis induction and commitment to apoptosis of $\mathrm{Kym}-1$ rhabdomyosarcoma cells
}

\author{
Peter Storz' ${ }^{1}$, Heike Döppler ${ }^{1}$, Judith Horn-Müller ${ }^{1}$, \\ Gertraud Müller ${ }^{1}$ and Klaus Pfizenmaier*,1 \\ 1 Institute of Cell Biology and Immunology, University of Stuttgart, Germany \\ * Corresponding author: K Pfizenmaier, Institute of Cell Biology and \\ Immunology, University of Stuttgart, Allmandring 31, D-70569 Stuttgart, \\ Germany. Tel: 49711685 6986; Fax: 49711685 7484; \\ E-mail: klaus.pfizenmaier@po.uni-stuttgart.de
}

Received 25.1.00; revised 9.6.00; accepted 19.6.00

Edited by D Wallach

\begin{abstract}
Growth of Kym-1 rhabdomyosarcoma cells depends on endogenous receptor tyrosine kinase signals activated by insulin and insulin-like growth factors (IGF), as revealed from enhancement of proliferation by insulin and IGF-1 and cytostatic action of inhibitors of IR/IGFR kinases. Depending on the presence or absence of the caspase inhibitor Z-VADfmk, TNF induced full growth arrest or apoptosis, respectively, indicating dominance of TNF over mitogenic signal pathways in Kym-1 cells. In accordance with a caspase-independent cytostatic action, TNF downregulated IR kinase activity and caused a profound inhibition of downstream mitogenic signals including the MAPK cascade and STAT5, key pathways of proliferation and cell survival. Removal of zVAD-fmk after $24 \mathrm{~h}$ induced rapid cell death in the absence of TNF. The inhibition of survival signals concomitant with persisting proapoptotic signals may tip the balance towards an irreversible commitment of the cell to apoptosis that becomes apparent upon relief of suppression of effector caspases. Cell Death and Differentiation (2000) 7, 955-965.
\end{abstract}

Keywords: TNF signal crosstalk; MAPK pathway; STAT5; growth arrest; apoptosis

Abbreviations: EMSA, electrophoretic mobility shift assay; GLUT4, glucose transporter 4; IR $\beta$, insulin receptor $\beta$ chain; IGFR, insulin-like growth factor receptor; IRS-1, insulin receptor substrate 1; JNK, c-Jun-N-terminal kinase; MAPK, mitogen-activated protein kinase; NF- $\kappa \mathrm{B}$, nuclear factor- $\kappa \mathrm{B}$; NIDDM, non-insulin-dependent diabetes mellitus, $\mathrm{PIP}_{3}$, phosphatidylinositol-3,4,5-trisphosphate; TNF/R, tumor necrosis factor/receptors; RTK, receptor tyrosine kinases; STAT5, signal transducerand activator of transcription 5; ZVAD-fmk, z-Val-Ala-DL-Asp-fluoromethylketone

\section{Introduction}

Tumor necrosis factor (TNF) is an important mediator of inflammation and inducer of cell death in a variety of cell types via TNF-R1 and TNF-R2-dependent engagement of multiple signal pathways, typically resulting in NF- $\kappa \mathrm{B}$ and JNK activation in virtually all cells, as well as induction of caspase cascades in cells sensitive to apoptosis (for reviews see ${ }^{1,2}$ ). Due to the potentially simultaneous activation of pro- and antiapoptotic signal pathways by TNF, the cellular context, i.e. the qualitative and quantitative constitution with the respective signal components, determines the cellular fate in response to TNF. In addition to the direct activation of proinflammatory and apoptotic signal cascades, it becomes increasingly evident that TNF signals also affect other signal cascades and, in particular, interfere with several receptor tyrosine kinasemediated activities. For example, the TNF crosstalk with insulin signal pathways has received much attention in recent years, because a link and potential causal relationship to the development of insulin resistance, a widespread pathophysiological condition leading to NIDDM, has been proposed. ${ }^{3}$ This is based on both in vitro cell models with adipocytes and hepatocytes, where TNF interfered with insulin-induced IR activation, ${ }^{4,5}$ as well as in vivo models of genetic or dietary development of obesity and diabetes, showing amelioration of insulin resistance in TNF- or TNFR-k/o mice. ${ }^{6}$ The responsible molecular mechanisms of this TNF crosstalk are not yet understood and may operate at various levels of the insulin signal cascade, probably involving a downregulation of the glucose transporter GLUT4 itself, ${ }^{7}$ inhibition of IRS-1 function, ${ }^{5,8,9}$ and direct inhibition of IR $\beta$ kinase activity. ${ }^{10-12}$ However, the partial inhibition of IR $\beta$ kinase activity appears by itself not sufficient to explain reduced glucose uptake, as in muscle cells the latter is not affected by TNF despite a down-regulation of IR $\beta$ kinase and immediate downstream substrates. ${ }^{13}$ In addition to the prominent IR signal tranducer IRS-1, STAT5b was recently recognized as a direct substrate. ${ }^{12,14,15}$ Both, IRS-1 and STAT5b are considered as important regulators of proliferative and antiapoptotic responses. ${ }^{16-22}$ IRS-1 proteins act as interfaces between stimulated receptors and downstream signaling proteins with $\mathrm{SH} 2$ (src homology 2) domains such as Grb2 and Shc, which activate the MAP kinase (MAPK) cascade $^{23-25}$ and PI 3-kinase (phosphatidylinositol-3-OH kinase), whose product $\mathrm{PIP}_{3}$ (phosphatidylinisitol-3,4,5-trisphosphate) is an activator of Akt/PKB (protein kinase B). Interestingly, not only Akt/PKB, which function to promote cell survival by inhibiting apoptosis at various levels, ${ }^{26,27}$ but also STAT5 are constitutively active in an apoptosis-resistant cell line ${ }^{22}$ suggesting that besides Akt/PKB, STAT5 and STAT5 
dependent genes also might play a role in the prevention of apoptosis. Accordingly, TNF mediated crosstalk with insulin signaling could extend beyond an interference with insulin's immediate metabolic effects causing insulin resistance and affect signal pathways regulating the transcriptional program and cellular functions related to growth control and survival.

To further substantiate at a molecular level the extent of the TNF crosstalk with mitogenic RTK-mediated signals induced by insulin and to analyze the functional consequences with respect to growth control and apoptosis sensitivity, we have studied a human rhabdomyosarcoma cell line, Kym-1. Although these cells display an endogenous activation of the related insulin-like growth factor receptor (IGFR), which shares the activation of several intracellular signal pathways, in particular IRS-1 activation, with the $\mathrm{IR},{ }^{28} \mathrm{Kym}-1$ cells are responsive to exogenous insulin treatment with respect to IRS-1 activation. ${ }^{15}$ As Kym-1 cells are also highly sensitive to TNF and rapidly undergo apoptosis, ${ }^{29,30}$ the insulin signal pathways potentially affected by TNF were investigated under conditions of blocking the apoptotic effector phase by caspase inhibitors. The data obtained show an early inhibition of insulininduced mitogenic and potentially antiapoptotic signals, resulting in a complete growth arrest during a two day culture. In parallel, within $24 \mathrm{~h}$, cells become irreversibly committed to death; upon removal of the broad spectrum caspase inhibitor z-VAD-fmk, cells undergo apoptosis in the absence of exogenous TNF. The rapid, profound and lasting inhibition of mitogenic/antiapoptotic signals could be an essential step towards progression to apoptosis.

\section{Results}

\section{Kym-1 rhabdomyosarcoma growth depends on functional insulin/IGF signal pathways}

The functionality of the IR signaling was first verified by Western blot analyses of tyrosine phosphorylation of immunoprecipitated IR $\beta$ and IRS-1. Upon insulin treatment of Kym- 1 cells, both, IR $\beta$ and IRS-1, were rapidly tyrosine phosphorylated reaching maximum phosphorylation within 1 min of stimulation and a subsequent slow decrease with still elevated phosphorylation of both molecules detectable after 60 min (Figure 1A). Of note, IRS-1 already showed weak, but clearly discernable tyrosine phosphorylation in untreated cells, indicating constitutive IRS-1 activation under standard cell culture conditions, probably due to endogenous IGFR signaling, a major mitogenic signal pathway of rhabdomyosarcoma cells. ${ }^{31}$ Although growth of $\mathrm{Kym}-1$ cells was largely independent of addition of insulin and IGF-1 to a complete culture medium, under reduced serum conditions the mitogenic effect of both insulin and IGF-1 became apparent (Figure 1B). Insulin treatment resulted in an increase in thymidine incorporation, which could be blocked by the tyrosine kinase inhibitors Tyrphostin AG1024 (Figure 1C) and $\mathrm{HNMPA}[\mathrm{AM}]_{3}$ (data not shown) below the basal level of thymidine incorporation of untreated cells. As these substances are considered to selectively inhibit IR and IGFR, but not EGFR kinase ${ }^{32,33}$ a role of a constitutively active IGFR signal pathway for proliferation of Kym-1 cells is suggested.
Both inhibitors caused a dose-dependent inhibition of proliferation (Figure 1D, E), but not induction of apoptosis (as revealed from microscopical examination as well as propidium iodide staining, data not shown) within the observation period. In fact, at the highest dose employed, a complete growth arrest was achieved as evident from the MTT signal obtained from an aliquot of freshly seeded cells stained directly after attachment to culture dishes (Figure 1D, E), asterisk and dotted line). Together, these data suggest an essential participation of IR/IGFR induced signals to the proliferative capacity of Kym-1 cells.

\section{TNF down-regulates insulin-induced activation of mitogenic signal pathways in Kym-1 cells}

Recently, a negative regulatory crosstalk between insulin and TNF signaling cascades has been identified, a hallmark being the inhibition of insulin-induced, GLUT4-mediated glucose uptake in adipocytes, ${ }^{4}$ whereas in muscle cells, this crosstalk does apparently not affect glucose transport. ${ }^{13} \mathrm{Kym}-1$ cells are TNF-responsive as evident from rapid, but transient NF$\kappa \mathrm{B}$ activation (Figure $2 \mathrm{~A}$ ), and the later induction of apoptosis without conditioning of the cells by protein synthesis inhibitors ${ }^{29,30}$ (Figure 4A). In accordance with previous results obtained in other cell models ${ }^{4,5,11,12}$ a $2 \mathrm{~h}$ TNF pretreatment of Kym-1 cells resulted in a typical amelioration of the subsequent insulin response, with a partial $(30-50 \%)$ reduction of $\mathrm{IR} \beta$ kinase activity (Figure $2 \mathrm{~B}$ ). In these cells, significant TNF mediated caspase activation can only be revealed after approximately $3 \mathrm{~h}$ of TNF treatment. ${ }^{30}$ Nevertheless, to ensure that low levels of active caspases did not influence early events in the signal crosstalk between TNF and insulin, z-VAD-fmk, an effective, broad spectrum inhibitor of caspases, ${ }^{34}$ was added throughout the TNF pretreatment and subsequent stimulation period. Immunoblot analyses verified down-regulation of IR $\beta$ kinase activity by TNF also in the presence of z-VAD-fmk (Figure $2 \mathrm{C}$ ), indicating caspase independence of this inhibitory crosstalk. As a consequence of reduced insulin receptor kinase activity, tyrosine phosphorylation of the direct substrates IRS-1 and STAT5b was reduced to the same or greater extent as the IR without decrease in protein levels (Figure 2D, E). Since STAT5b tyrosine phosphorylation is an absolute prerequisite for nuclear translocation and transcriptional activity, EMSA analyses were performed to investigate the functional significance of reduced tyrosine phosphorylation of STAT5b. Interestingly, upon TNF pretreatment of Kym-1 cells, insulininduced STAT5b translocation was completely blocked (Figure 2F). These data already indicate that the crosstalk of TNF also affects insulin-induced transcriptional programs, which was further corroborated by studying the influence of TNF on insulin's mitogenic activities via IRS-1 and Shc, which converge at the level of Raf- 1 as the upstream activator of the MAPK cascade.

Upon TNF pretreatment of Kym-1 cells, insulin-mediated induction of the MAPK cascade was significantly reduced. This was revealed from direct and linked Raf-1 kinase assays, using c-Raf-1 immunoprecipitations from stimulated Kym-1 cells and GST-MEK1 (Figure 2G, middle panel), or GST-MEK1 and kinase-negative GST-Erk1 (Figure 2G, 
lower panel) as substrates for in vitro kinase assays. TNF pretreatment did not influence protein levels of $c$-Raf-1
(Figure 2G, upper panel). Further, Erk2 immunoprecipitates and Erk2 kinase assays using MBP as a substrate verified
A

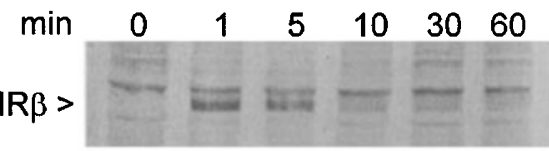

IP: IR $\beta$ Detection: PY

$\begin{array}{lllllll}\min & 0 & 1 & 5 & 10 & 30 & 60\end{array}$

IRS-1 >

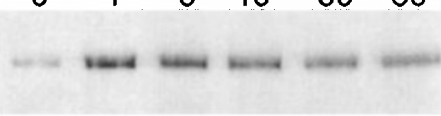

IP: IRS-1 Detection: PY

C DNA Synthesis 16 hrs
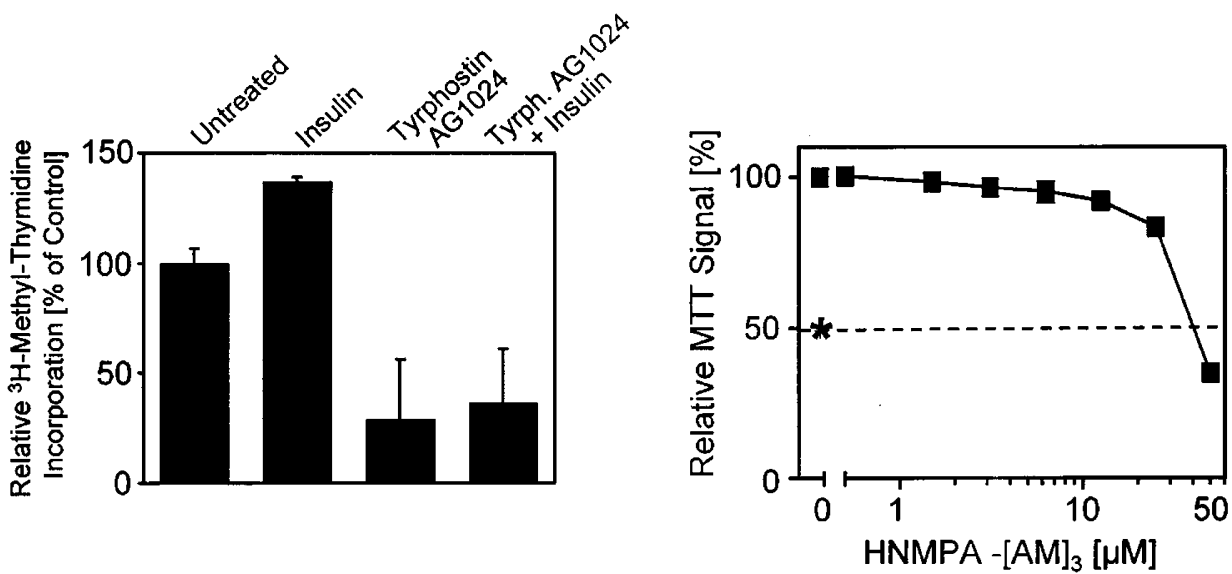

B Viable Cells 96 hrs

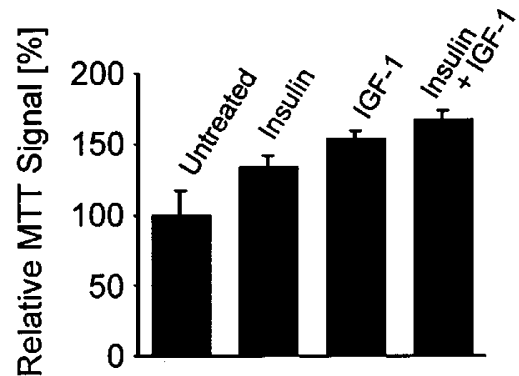

D Viable Cells $48 \mathrm{hrs}$
E Viable Cells $48 \mathrm{hrs}$

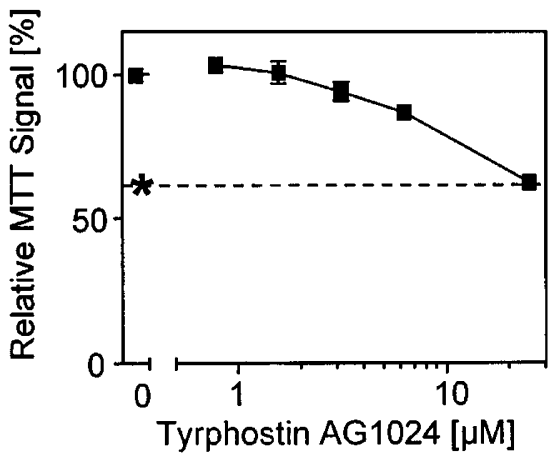


A
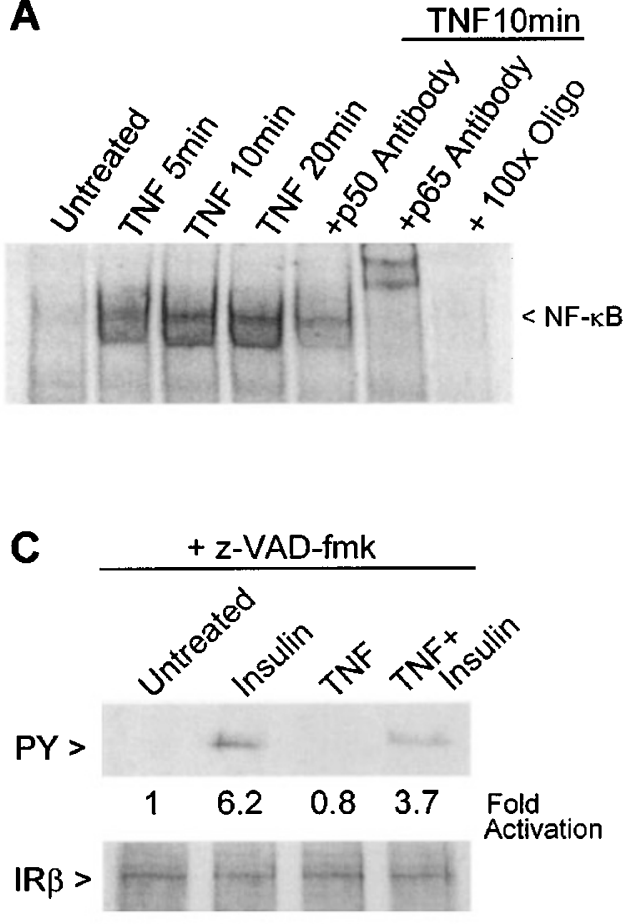

IP: IR

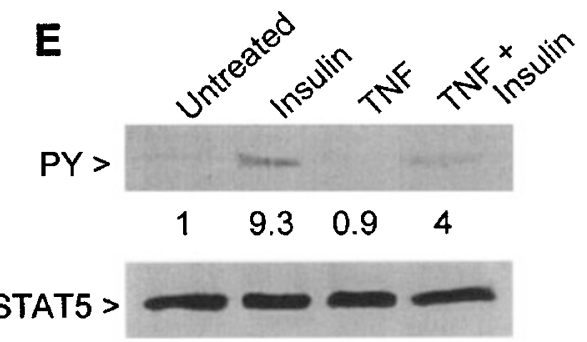

IP: STAT5b

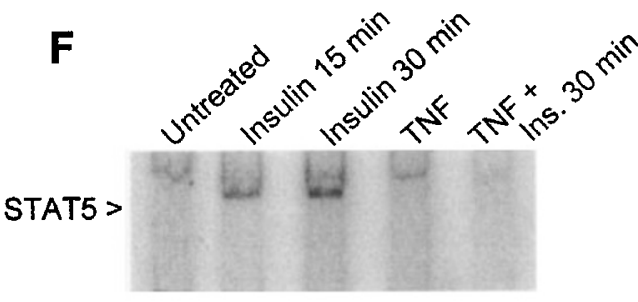

\section{STAT5 EMSA}

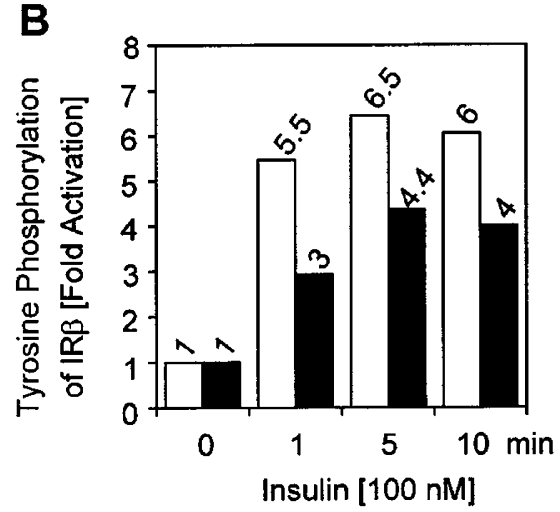

D

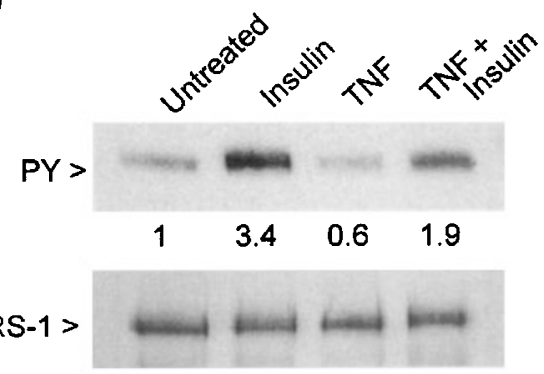

IP: IRS-1
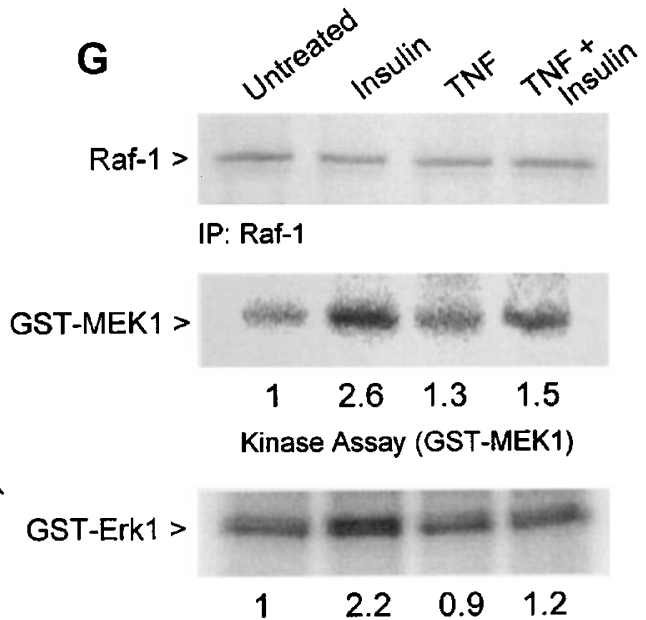

Kinase Assay (GST-MEK1, GST-Erk1)

Figure 2 TNF signaling and crosstalk with insulin-induced mitogenic signal pathways in Kym-1 cells. (A) Activation of $p 50 / p 65$ NF- $\kappa$ B homo/heterodimers by TNF. $10^{6} \mathrm{Kym}-1$ cells were serum-starved for $2 \mathrm{~h}$ and stimulated with TNF $(50 \mathrm{ng} / \mathrm{ml})$ for the indicated times. Nuclear extracts were prepared, EMSA and 'supershift' EMSA were performed as described in Materials and Methods. The specificity of the NF- $k$ B/oligonucleotide interaction was determined by competition with an excess of 100 -fold non radio-labeled oligonucleotide. (B) Time course of TNF-induced inhibition of IR $\beta .5 \times 10^{6} \mathrm{Kym}-1$ cells were serum-deprived and preincubated for $2 \mathrm{~h}$ without or with TNF $(50 \mathrm{ng} / \mathrm{ml})$. After stimulation with insulin $(100 \mathrm{nM})$ for indicated times cells were lysed in lysis buffer and IR $\beta$ was immunoprecipitated. The immunoprecipitates were run on SDS - PAGE, transferred to nitrocellulose and Western blotting with phosphotyrosine specific (PY99) and IR $\beta$ specific antibody was performed. Densitometric evaluation of blots was done with a phosphoimager and fold activation of the IR kinase of insulin-treated cells relative to untreated cells is shown above the bars (white bars=insulin stimulation; black bars=TNF pretreatment before insulin stimulation). (C) Inhibition of insulin-induced IR $\beta$ activity by TNF in presence of z-VAD-fmk. Kym-1 cells were treated as in B plus addition of z-VAD-fmk (20 $\mu$ M) during TNF pretreatment. Insulin stimulation (100 nM) was for $5 \mathrm{~min}$, cell lysates, immunoprecipitation and Western blotting were done as in B. (D) Inhibition of insulin-induced tyrosine phosphorylation of IRS-1 by TNF. IRS1 was immunoprecipitated from $5 \times 10^{6} \mathrm{Kym}-1$ cells pretreated as in $\mathbf{B}$, upon insulin stimulation $(100 \mathrm{nM})$ for 5 min. The blot was immunostained with antibodies against PY (PY99) or IRS-1. (E, F) Inhibition of insulin-induced activation of STAT5 by TNF in Kym-1 cells. (E) STAT5 was immunoprecipitated from $5 \times 10^{6} \mathrm{Kym}-1$ cells pretreated as in B and stimulated with insulin (100 nM) for $30 \mathrm{~min}$. The blot was stained with PY (4G10, upper panel) or STAT5b antibodies (G2, lower panel). (F) EMSA analysis of STAT5 activation. $10^{6} \mathrm{Kym}-1$ cells were pretreated as in $\mathbf{E}$ and stimulated with insulin ( $\left.100 \mathrm{nM}\right)$ for 15 or $30 \mathrm{~min}$, all in the presence of $20 \mathrm{mM}$ 
that insulin-induced Erk2 activity was also completely abolished upon TNF pretreatment (data not shown).

Thus TNF inhibits insulin/IGF-1 mediated growth signals within a time period, at which caspase activation is not yet detectable, and where cytotoxic actions can be rescued by the addition of caspase inhibitors. ${ }^{30}$ In order to investigate whether these inhibitory effects are only transient or persist over a long time period, long term (up to $48 \mathrm{~h}$ ) TNF treatment of Kym-1 rhabdomyosarcoma cells was performed in the presence of the broad spectrum caspase inhibitor Z-VAD-fmk in order to prevent apoptosis. The data obtained revealed a lasting, profound inhibition of tyrosine phosphorylation at both insulin receptor and IRS-1 levels (Figure 3A, C). A similar degree of inhibition could be obtained when the cells were cultured in the presence of Tyrphostin AG1024 before insulin stimulation (Figure 3B, $D)$. In both cases no changes in the protein levels of IR and IRS-1 were observed.

\section{TNF induces growth inhibition and morphological changes when apoptosis is blocked}

Kym-1 cells are highly sensitive to TNF induced apoptosis, with nearly complete cell death already at $100 \mathrm{pg} / \mathrm{ml}$ of TNF
A

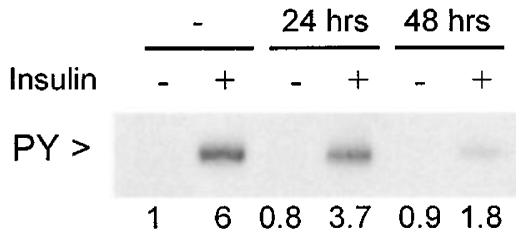

$\operatorname{IR} \beta>$

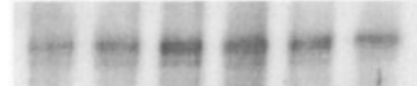

C

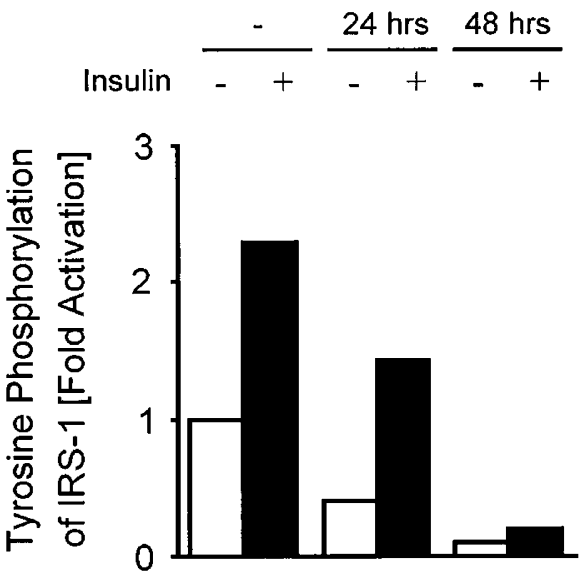

B

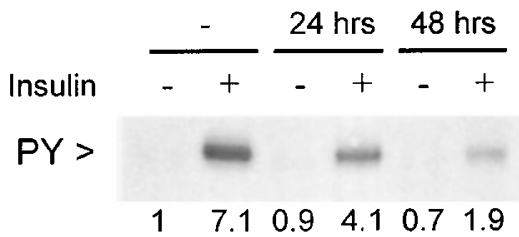

$\operatorname{IR} \beta>$

D Tyrphostin AG1024 Insulin $\frac{-}{-+} \frac{24 \mathrm{hrs}}{-++} \frac{48 \mathrm{hrs}}{-+}$

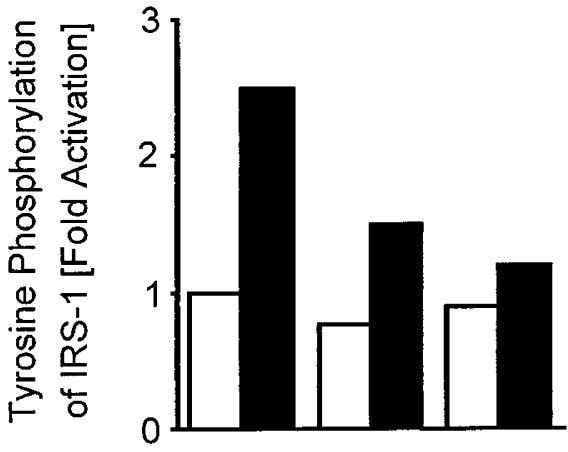

Figure 3 Inhibition of insulin signals after long-term treatment with TNF/z-VAD-fmk or Tyrphostin AG1024. Kym-1 cells were pretreated with TNF (50 ng/ml) and zVAD-fmk $(20 \mu \mathrm{M})$, or with Tyrphostin AG1024 $(25 \mu \mathrm{M})$ for 24 or $48 \mathrm{~h}$. Insulin stimulation $(100 \mathrm{nM})$ was for $5 \mathrm{~min}(\mathbf{A}, \mathbf{B})$ IR $\beta$ was immunoprecipitated from $5 \times 10^{6} \mathrm{Kym}$ 1 cells and Western blotting against PY (4G10) was performed (upper panel). The blot was stripped and re-probed against the IR $\beta$-chain (lower panel). (C,D) IRS-1 was immunoprecipitated from $5 \times 10^{6} \mathrm{Kym}-1$ cells. Western blotting with antibodies against PY (4G10), and re-probing of the blot against IRS-1 was performed Basal IRS-1 tyrosine phosphorylation was set as 1 . All experiments have been performed three times with similar results

sodium vanadate. Nuclear extracts were prepared and STAT5 EMSA was performed. (G) Inhibition of insulin-induced Raf- 1 activation by TNF. $5 \times 10^{6}$ Kym- 1 cells were kept in $0.5 \%$ FCS containing medium over night. Prior to the stimulation they were pretreated as in B and then stimulated with insulin (100 $\mathrm{nM}$ ) for 1 min. Raf- 1 kinase was immunoprecipitated and kinase assays were performed. Upper panel shows immunoprecipitated Raf-1 kinase, indicating equal amounts of protein in the precipitates. Lower two panels show a direct kinase assay of immunoprecipitated Raf-1 kinase using inactive GST-MEK1 as a substrate (middle panel) and a linked kinase assay with GST-MEK1 and kinase dead GST-Erk1 as substrate (lower panel). The samples were run on SDS-PAGE and transferred to nitrocellulose and analyzed with a phosphoimager. All experiments have been performed three times with similar results 
(Figure 4A). In order to reveal functional consequences of the TNF insulin crosstalk independent of concomitantly ongoing apoptotic processes, that are likely to blur other intracellular signals and cellular responses, culture and stimulation of the cells was done in the presence of z-VAD-fmk. Under these conditions, a cytostatic action of TNF became apparent, reaching full growth arrest at around $10 \mathrm{ng} / \mathrm{ml}$ (Figure 4A). Although in the same cell line, the TNF dose is significantly higher than that required for induction of apoptosis, it is just around the concentration necessary to reach saturation

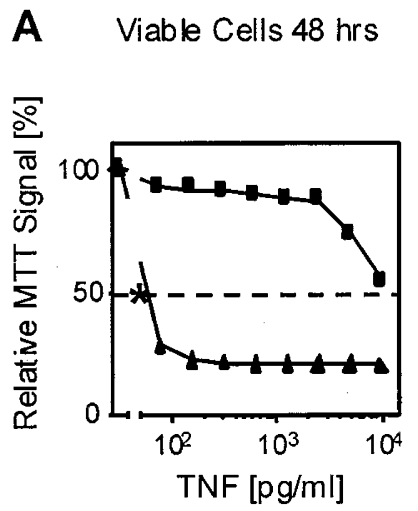

D Propidium lodide Staining
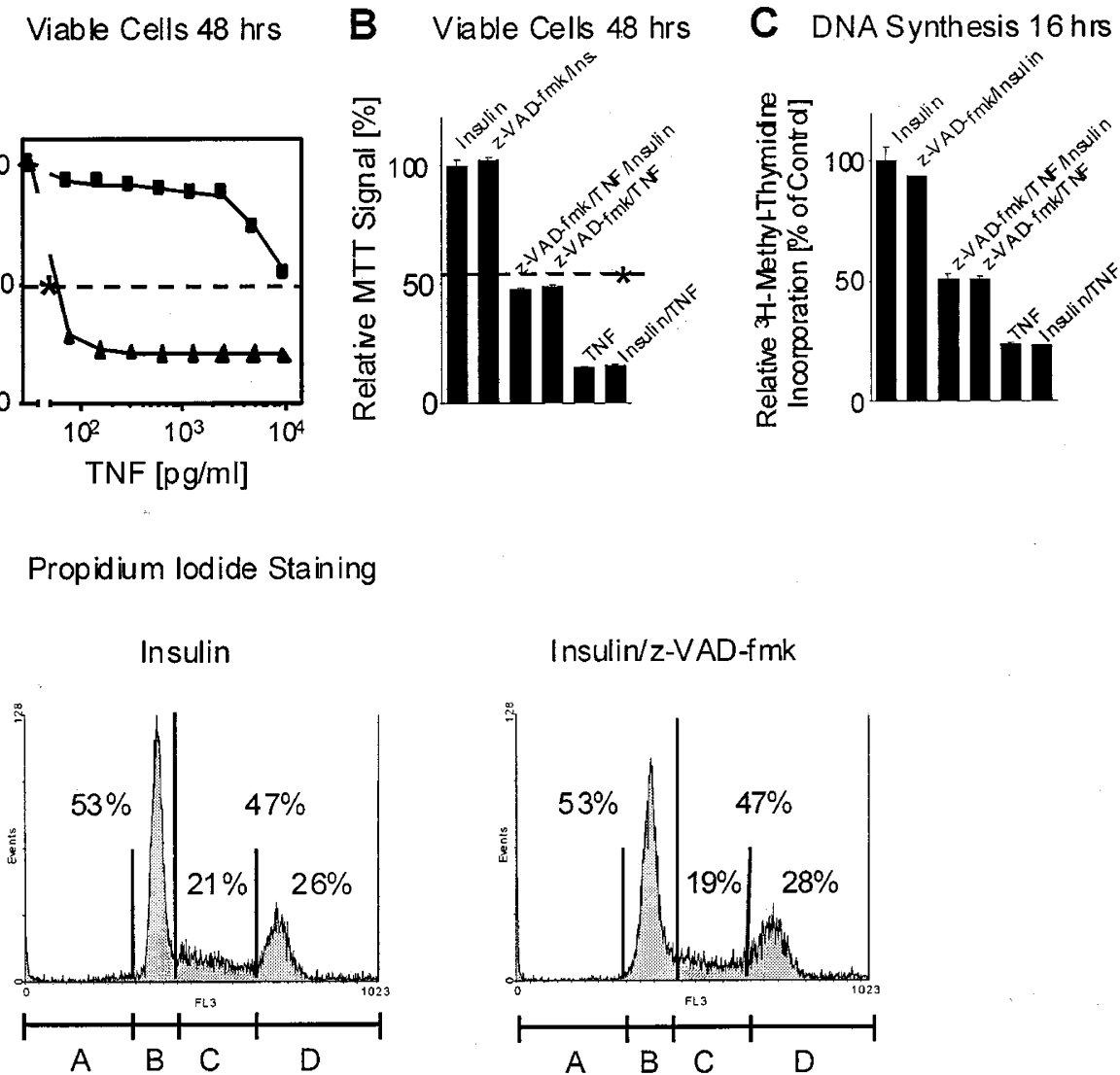

Insulin/z-VAD-fmk

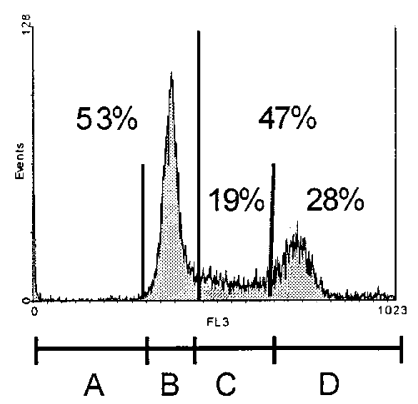

Insulin/z-VAD-fmk/TNF
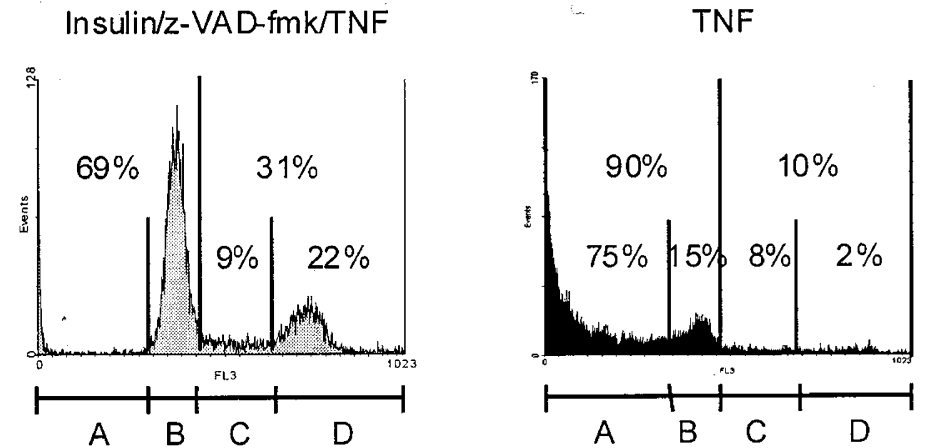

Figure 4 Cytostatic action of TNF in presence of z-VAD-fmk. (A) Differential sensitivity to the cytotoxic and cytostatic action of TNF. $10^{5}$ Kym-1 cells were incubated for $48 \mathrm{~h}$ with the indicated concentrations of TNF in the presence (filled squares) or absence (filled triangles) of z-VAD-fmk ( $20 \mu \mathrm{M})$. Viable cells were determined by MTT assay. The MTT signal of an aliquot of cells stained directly after attachment (asterisk and dotted line) is shown as a reference to the proliferation of untreated cells after $48 \mathrm{~h}$, the latter value was arbitrarily set as $100 \%$. (B,C) Insulin costimulation does not prevent TNF's cytotoxic or cytostatic action. (B) MTT assay. Kym-1 cells were treated for $48 \mathrm{~h}$ as indicated (insulin $100 \mathrm{nM}$; TNF $50 \mathrm{ng} / \mathrm{ml}$; z-VAD-fmk $20 \mu \mathrm{M}$ ) in cell culture medium containing $10 \%$ FCS. Asterisk and dotted line indicate the MTT signal of the cells at onset of culture. (C). Thymidine incorporation. After attachment, Kym-1 cells were treated as indicated (insulin $100 \mathrm{nM}$; TNF $50 \mathrm{ng} / \mathrm{ml}$; z-VAD-fmk $20 \mu \mathrm{M}$ ) for $16 \mathrm{~h}$ in the presence of ${ }^{3} \mathrm{H}$-thymidine according to Materials and Methods. (D) Cell cycle analyses of propidium iodide stained Kym-1 cells treated for $8 \mathrm{~h}$ either with insulin $(100 \mathrm{nM})$ only, insulin $(100 \mathrm{nM}) / z-V A D-f m k(20 \mu \mathrm{M})$, insulin $(100 \mathrm{nM}) / \mathrm{z}-\mathrm{VAD}$-fmk $(20 \mu \mathrm{M}) / \mathrm{TNF}$ $(50 \mathrm{ng} / \mathrm{ml})$ or TNF $(50 \mathrm{ng} / \mathrm{ml})$ only. Propidium iodide staining was performed as described in Materials and Methods. The samples were analyzed by flow cytometry. (area A: hypoploid nuclei indicating apoptic cells; area B: cells in G0/G1 phase; area C: cells in S phase; area D: cells in G2/M phase). Shown is one representative experiment out of five with similar results 
binding to membrane expressed TNF-R1, ${ }^{35}$ the receptor responsible for induction of apoptosis ${ }^{36}$ and signal crosstalk with insulin. ${ }^{12}$ Insulin did neither prevent TNF's apoptotic activity on Kym-1 cells nor, when apoptosis was blocked by zVAD-fmk, its cytostatic action, as revealed from MTT assays after $48 \mathrm{~h}$ (Figure 4B) and thymidine incorporation assays after $16 \mathrm{~h}$ (Figure 4C). The dominant cytostatic action of TNF thus resembles the action of the RTK inhibitors (Figure 1) and is in full accordance with the biochemical data (Figures 2 and 3), showing TNF mediated inhibition of insulin-induced mitogenic signal cascades. TNF-mediated induction of cytostasis, in the presence of z-VAD-fmk, was independently confirmed by cell cycle analyses using flow cytometry of propidium iodide stained Kym-1 cells after $8 \mathrm{~h}$ of treatment. These experiments provided clear evidence for a growth arrest, but not apoptosis, by accumulation of insulin/TNF/zVAD-fmk treated cells in G0/G1 (area B) in the absence of hypoploid cells (area A) (Figure 4D, lower left panel),
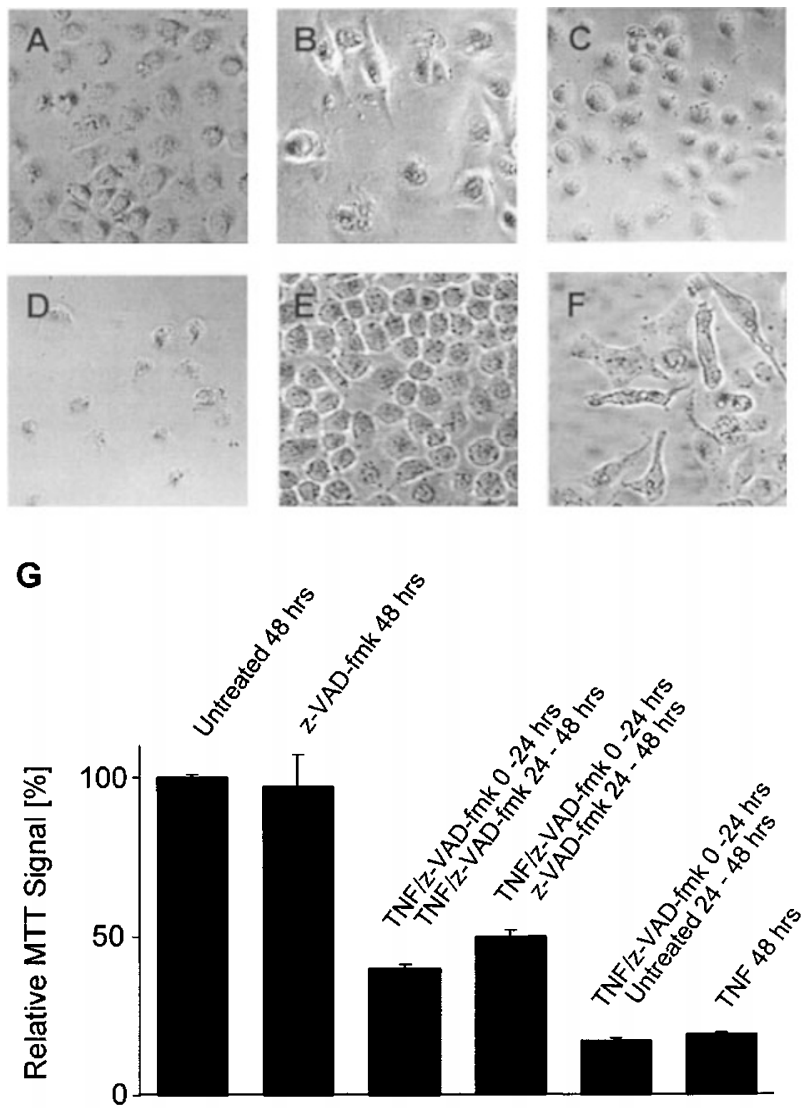

Figure 5 TNF induces morphological changes in Kym-1 cells when apoptosis is blocked by caspase inhibitors. Kym-1 cells were incubated $48 \mathrm{~h}(\mathbf{A}-\mathbf{D})$ and $96 \mathrm{~h}(\mathbf{E}, \mathbf{F})$ either with $20 \mu \mathrm{M}$ z-VAD-fmk plus $50 \mathrm{ng} / \mathrm{ml}$ TNF (B and $\mathbf{F}$ ), with $20 \mu \mathrm{M}$ z-VAD-fmk (C), or left untreated (A and E). In (D), after $24 \mathrm{~h}$ the culture medium containing TNF+Z-VAD-fmk was changed into standard growth medium. Shown are phase contrast pictures (final magnification $\times 40$ ). $(\mathbf{G})$ Kym- 1 cells were preincubated for $24 \mathrm{~h}$ with z-VAD-fmk $(20 \mu \mathrm{M})$ plus TNF $(50 \mathrm{ng} / \mathrm{ml})$, as controls with z-VAD-fmk or TNF alone, or were left untreated. After $24 \mathrm{~h}$ the culture medium was changed into standard growth medium containing indicated agents. After additional $24 \mathrm{~h}$ a MTT assay was performed. The MTT signal obtained from untreated cells $(48 \mathrm{~h})$ served as reference and was set $100 \%$. The experiments have been performed three times with similar results compared to non TNF treated controls (Figure 4D, insulin and insulin/z-VAD-fmk, upper panels, respectively). Interestingly, the most prominent changes were observed in the fraction of cells entering the S-phase of cell cycle, with a reduction from 20 to $9 \%$, whereas the number of cells in G2/M didn't drop so much (27 and $22 \%$ for controls and TNF, respectively). The same result was obtained when cell cycle analysis was performed at $96 \mathrm{~h}$ of combined TNF/z-VAD-fmk treatment (data not shown). This suggests that TNF affects early and late restriction points in cell cycle, namely entry into S-phase, as well as entry into and/or exit from mitosis.

Upon persisting blockade of caspases by z-VAD-fmk, prolonged TNF treatment of Kym-1 rhabdomyosarcoma cells resulted in gross changes of the cell morphology, detectable at $48 \mathrm{~h}$ of culture (Figure $5 \mathrm{~B}$ ), but more prominent at $96 \mathrm{~h}$ (Figure $5 \mathrm{~F}$ ) in comparison to untreated (Figure 5A, E), or z-VAD-fmk treated control cells (Figure $5 \mathrm{C})$. At the latter time point, TNF treated cells showed, in comparison to controls, a stretched-out irregular shape and an approximately doubled size. This morphological alteration is, in contrast to the parallel, irreversible commitment to apoptosis, a rather slow process that is reversible at least during the first $24 \mathrm{~h}$ of treatment. Thus, growth inhibited Kym-1 cells apparently resumed growth upon removal of TNF when z-VAD-fmk treatment was continued (Figure $5 G$ ), whereas upon simultaneous removal of TNF and the caspase inhibitor z-VAD-fmk from the culture after $24 \mathrm{~h}$, the cells undergo apoptosis without further exogenous signals (Figure 5D, G), indicating the latent proapoptotic state of the cell.

\section{Discussion}

We here show that the rhabdomyosarcoma cel line Kym-1 is a suitable model to study signal crosstalk of cell death and cell growth inducing ligands. In vitro proliferation of this cell line depends on endogenous and exogenously triggered activity of insulin and IGF receptor tyrosine kinases, evident from cytostasis induced by inhibitors of these kinases (Figure 1). On the other hand, Kym-1 cells are highly sensitive to TNF, ${ }^{29}$ with rapid, but transient NF- $\kappa$ B activation and, upon persistent TNF exposure for several hours, induction of apoptosis. ${ }^{30}$ The TNF signal crosstalk with insulin occurs early, before caspases are activated and other, irreversible apoptotic processes ensue. TNF induced signals affect the IR kinase activity itself and, to a greater extent, several downstream targets of the IR along the mitogenic and survival signal pathways of insulin, specifically ERKs as well as STAT5b (Figure 2). Both, STAT5 and MAPK are considered as typical positive regulators of cell cycle progression. As for STAT5, nuclear translocation is also a prerequisite for MAPK to promote entry into the cell cycle. ${ }^{37,38}$ Therefore, our data provide a new perspective to mechanisms of TNF crosstalk with mitogenic signaling cascades that becomes manifested at the transcriptional level due to preventing activation of nuclear MAPK targets and of STAT5 regulated genes. Accordingly, we suggest that inhibition of both, STAT5 and MAPK activation contributes to the cytostatic action of TNF. By a block of the execution of apoptosis with the specific caspase inhibitor z-VAD-fmk, we were further able to 
investigate the long term consequences of TNF's crosstalk with these mitogenic signal pathways. A persistent inhibition of the IR $\beta$ kinase activity by TNF (Figure 3), as well as a potent cytostatic activity of TNF on Kym-1 cells similar to RTK inhibitors (Figure 4) became apparent under these conditions. Thus, the close correlation of the observed TNF-mediated cytostasis in Kym-1 cells and TNF-mediated inhibition of signal pathways considered as important positive regulators of the cell cycle suggest a causal relationship.

Several mechanisms have been previously described influencing the activation status of the insulin receptor $\beta$ chain. Serine phosphorylation of $\mathrm{IR} \beta$, as well as of IRS-1 are discussed to induce insulin resistance, and can occur within few minutes after TNF treatment. ${ }^{5,8-10,53}$ In Kym-1 cells treatment with TNF ( $1 \mathrm{~min}$ to $2 \mathrm{~h}$ ) following stimulation with insulin did not lead to co-immunoprecipitation of IRS-1 in IR $\beta$ immunoprecipitates (data not shown); the latter could be taken as indication of a rapid inhibition of $\operatorname{IR} \beta$ by serine phosphorylated IRS-1, as it was described before. ${ }^{5,8}$ Due to lack of experimental evidence supporting such a mechanism in Kym-1 cells, we conclude that another mechanism i.e. the activation of tyrosine phosphatases might be responsible for the reduction in tyrosine phosphorylation. It was shown before that the tyrosine phosphatase inhibitor orthovanadate can suppress the inhibitory effects of TNF on insulin signaling cascades. ${ }^{54}$ Therefore, it is reasonable to assume that in our cellular system the primary inhibitory effect occurs directly at the insulin receptor $\beta$-chain. The direct substrates of the insulin receptor, IRS-1 and STAT5b, are both implicated in proliferative signaling. ${ }^{16-19}$ A TNF mediated down-regulation of IRS-1 signals appears of significance, as IRS-1 takes a central position converging both survival and mitogenic signals, in particular activation of PI 3-kinase, Akt-1 (PKB) and MAPK, which mediate proliferative as well as antiapoptotic signals. ${ }^{26,27,39}$ The insulin-mediated activation of STAT5b and its inhibition by TNF in Kym-1cells is in accordance with recent own and other data demonstrating that STAT5 is directly phosphorylated by the insulin receptor kinase ${ }^{14}$ and that TNF induced inhibition of insulin-mediated STAT5b tyrosine phosphorylation results in complete loss of STAT5b nuclear translocation. ${ }^{12}$ The physiological function of STAT5 is apparently complex and not fully elucidated yet. ${ }^{37,40}$ However, an involvement of STAT5 in survival and proliferation of different cell types is emerging from several studies. ${ }^{17,18,21,41}$ STAT5 is capable to act in concert with other transcription factors, ${ }^{42}$ and for different STAT family members, including STAT5a, an interaction with MAPK signaling pathways in RTK and insulin signaling were implicated. ${ }^{43,44}$ Moreover, in several cells the disruption of the STAT, as well as the Raf-1/MAP kinase pathways blocks survival factors targeting proapoptotic molecules. ${ }^{45,46}$

In insulin signaling, the activation of Raf-1/MAPK occurs via IRS-1 or Shc ${ }^{23,47}$ and takes a central position in mitogenic pathways of insulin and a variety of other growth factors. For example, overexpression of IRS-1 induced activation of MAPK, ${ }^{25}$ and adenovirus-mediated overexpression of IRS-1 interacting domains abolished insulinstimulated mitogenesis, without affecting metabolic effects like glucose transport. ${ }^{16}$ In Kym-1 cells, the partial inhibition of IR tyrosine phosphorylation after TNF treatment was correlated with a nearly complete loss of insulin-induced cRaf-1/MAPK activation. At the molecular level, this could be due to at least two, nonexclusive mechanisms: First, it is apparent that a reduced IR kinase activity and correspondingly reduced IRS-1 activation should have effects on downstream substrates. Second, a direct interference of TNF signals with Raf- 1 activation is conceivable. Indeed, evidence for the latter has recently been obtained by us in different cell models of a negative regulatory crosstalk of TNF with other typical mitogenic signals. Thus, we could show, e.g. for EGF-induced or V-src-induced MAPK activation, an inhibition of the MAPK cascade by TNF and its second messenger ceramide at the level of Raf- $1 .{ }^{48}$ Interestingly, ceramide, which is also reported to be an inhibitor of Akt/PKB, ${ }^{49}$ has been shown to induce G0/G1 arrest, but not apoptosis, in cells lacking TNF receptors. ${ }^{50}$ We here demonstrate for Kym-1 cells that, when the executing caspases are blocked, TNF is an effective cytostatic agent, able to completely inhibit cell proliferation of these transformed cells, apparently by interfering with several stages of the cell cycle.

Because of the multiplicity of signals conveyed by TNF, the growth arrest observed in Kym-1 cells is, unless caspases are blocked, a transient status, in which the cell is concomitantly primed for apoptosis. The rapid induction of cell death upon relief from caspase suppression after a $24 \mathrm{~h}$ TNF treatment in the presence of z-VAD-fmk is in accordance with the acquisition of a state of apoptotic dormancy, indicating that proapoptotic signals ensued in the presence of this caspase inhibitor to an irreversible commitment of the cells to die without further apoptotic signals by TNF. As discussed above, the interference of TNF with mitogenic signals simultaneously inhibits signal pathways leading to the activation of antiapoptotic molecules, such as IRS-1-dependent activation of Akt/ PKB. ${ }^{51}$ The early inhibition of antiapoptotic survival signals by TNF observed here for $\mathrm{Kym}-1$ cells is probably as important as generation of proapoptotic signals in defining cellular sensitivity to apoptosis. For Kym-1 cells the dominance of TNF over insulin action with respect to apoptosis induction is therefore not unexpected. However, for other cell models, a prevention of apoptotic signaling by insulin and FGF2 was demonstrated, ${ }^{20,45,52}$ indicating that in different cell types the extent and mode of signal crosstalk may differ significantly and thus largely influence the net cellular response to the same signals. The data together suggest that the cellular context determines whether the balance between pro- and antiapoptotic signals is shifted towards survival or rather cell death.

In conclusion, although the specific signal molecules within the TNF pathway responsible for interference with insulin signaling have yet to be revealed, it is apparent that TNF's crosstalk could be operative at multiple, receptor proximal and distal levels along mitogenic signal pathways, and thus makes it reasonable to assume that different TNFinduced signal molecules could be involved. In cells sensitive to TNF-induced apoptosis, such as Kym-1, the profound and lasting inhibition of mitogenic/anti-apoptotic 
signals appears to be an early and likely important step towards progression to apoptosis.

\section{Materials and Methods}

\section{Cell culture}

The human rhabdomyosarcoma cell line Kym-1 was cultured in Click's RPMI 1640 medium supplemented with $10 \%$ FCS. Kym-1 cells were grown to approximately $80 \%$ confluence in tissue culture plates and, where indicated, were kept under low serum conditions (Click's RPMI $1640,0.5 \%$ FCS) for $16 \mathrm{~h}$ before onset of experiments. Before treatment with TNF or insulin, Kym-1 cells were serum-deprived (Click's RPMI 1640, w/o FCS) for $2 \mathrm{~h}$, and stimulated as indicated for various concentrations and times.

\section{Cytokines, antibodies, and reagents}

Recombinant huTNF was a kind gift of BASF, Germany. Insulin from bovine pancreas was purchased from Sigma. Antibodies specific for insulin receptor $\beta$ (C19), IRS-1 (C20), STAT5 (G2, C17), c-Raf-1 (C12), PY (PY99), NF- $\kappa$ B p65 (SC109), and NF- $\kappa$ B p55 (SC114) were from Santa Cruz. 4G10 phosphotyrosine antibody was from Upstate. Secondary AP-linked antibodies, goat anti-mouse $\lg G$ and $\lg M(H+L)$ and goat anti-rabbit $\lg G(\mathrm{H}+\mathrm{L})$, were from Dianova. STAT5 oligonucleotides (5'-AGATTTCTAGGAATTCAATCC-3') were from Santa Cruz. NF- $\kappa$ B oligonucleotides (5'-ATCAGGGACTTTCCGCTGGGGACTTTCCG-3') were synthesized by MWG. All inhibitors of proteases and phosphatases were from Biomol. ZVAD-fmk (z-Val-Ala-DL-Asp-fluoromethylketone) was from BACHEM, HNMPA- $[\mathrm{AM}]_{3}$ (Hydroxy-2-naphtalenylmethylphosphonic acid tris acetoxymethyl ester) was from Calbiochem, and Tyrphostin AG1024 was from ALEXIS Corporation. GST-[K71A] Erk1 agarose conjugate and non-active GST-MAP kinase kinase 1 (GST-MEK1) were from Upstate. Propidium iodide was from Sigma.

\section{Cell lysis and immunoprecipitation}

After stimulation the cells were washed twice with PBS $\left(4^{\circ} \mathrm{C}\right)$ and scraped in $750 \mu \mathrm{l}$ ice-cold lysis buffer $(50 \mathrm{mM}$ Tris $/ \mathrm{HCl} \mathrm{pH} \mathrm{7.4,} 1 \%$ Triton X-100 (v/v), $150 \mathrm{mM} \mathrm{NaCl}, 5 \mathrm{mM}$ EDTA pH 7.4, $1 \mathrm{mM} \mathrm{NaF}$, $1 \mathrm{mM}$ NaPP, $2 \mathrm{mM}$ sodium orthovanadate, $1 \mathrm{mM}$ sodium molybdate, $100 \mathrm{nM}$ okadaic acid, $100 \mathrm{nM}$ calyculin A, $1 \mathrm{mM}$ p-nitrophenylphosphate, $1 \mu \mathrm{g} / \mathrm{ml}$ leupeptin, $1 \mu \mathrm{g} / \mathrm{ml}$ aprotinin, $1 \mathrm{mM} \mathrm{PMSF})$. After $1 \mathrm{~h}$ cell lysis, the lysates were centrifuged $\left(10000 \times \mathrm{g}, 15 \mathrm{~min}, 4^{\circ} \mathrm{C}\right)$ and immunoprecipitation ( $1 \mu \mathrm{g} / \mathrm{ml}$ antibody or antiserum per sample) was performed as described. ${ }^{12}$ Protein contents in lysates were determined with the Bio-Rad Protein Assay using BSA as a standard.

\section{Raf-1 kinase assay}

After immunoprecipitation of $\mathrm{c}-\mathrm{Raf}-1$, the Protein-A pellets were washed three times $(50 \mathrm{mM}$ Tris/ $\mathrm{HCl} \mathrm{pH} \mathrm{7.4,} 150 \mathrm{mM} \mathrm{NaCl})$, and resuspended in $30 \mu$ l kinase buffer $(20 \mathrm{mM}$ Tris/ $\mathrm{HCl} \mathrm{pH} \mathrm{7.4,50} \mathrm{mM}$ $\mathrm{NaCl}, 10 \mathrm{mM} \mathrm{MgCl}_{2}$ ). After addition of $4 \mu \mathrm{Ci}\left[{ }^{32} \mathrm{P}\right]-\gamma$-ATP (Amersham), and of substrates (500 ng GST-MEK1, $1 \mu \mathrm{g} \mathrm{GST-Erk1)} \mathrm{in} 10 \mu$ l kinase buffer, the samples were incubated for $30 \mathrm{~min}$ at $37^{\circ} \mathrm{C}$. The reaction was stopped by addition of $2 \times$ reducing Laemmli buffer. The samples were separated on $7.5 \%$ SDS-PAGE and transferred to nitrocellulose. Quantitative analyses of the kinase assays were performed with a phosphoimager (Molecular Dynamics).

\section{Electrophoretic mobility shift assay (EMSA)}

Oligonucleotides were ${ }^{32} \mathrm{P}$-labeled with polynucleotide kinase and EMSA was performed as described. ${ }^{12}$ For 'supershift' assays nuclear extracts were incubated with the specific antibodies for $N F-\kappa B$ subunits $(10 \mu \mathrm{l} / \mathrm{ml})$ for $1 \mathrm{~h}$ at $4^{\circ} \mathrm{C}$ prior to the EMSA.

\section{MTT assays and thymidine incorporation}

For MTT proliferation assays, 10000 or $2000 \mathrm{Kym}-1$ cells/well were seeded in 96-well plates in cell culture medium supplemented with $0.5 \%$ or $10 \% \mathrm{FCS}$. TNF, insulin, and/or inhibitors (z-VAD-fmk, Tyrphostin AG1024, HNMPA-[AM] $]_{3}$ ) were added as indicated. After $48 \mathrm{~h}$, the number of living cells was measured using the 'Cell Proliferation Kit I (MTT)' (Boehringer Mannheim), according to standard procedures. As a basal value, the MTT signal of an aliquot of cells seeded in parallel was determined directly after attachment (asterisks and dotted lines). For thymidine incorporation assays, $10000 \mathrm{Kym}-1$ cells/well were seeded in 96-well plates in cell culture medium supplemented with $10 \%$ of FCS as indicated. TNF, insulin, and/or inhibitors (z-VAD-fmk, Tyrphostin AG1024, or HNMPA-[AM $]_{3}$ ) were added after attachment of the cells. Two hours after stimulation of the cells thymidine $\left(1 \mu \mathrm{Ci}\right.$ [methyl- ${ }^{3} \mathrm{H}$ ] thymidine/sample) was added for $16 \mathrm{~h}$. The cells were harvested in a cell harvester, and radioactivity incorporated into DNA was measured by scintillation counting according to standard procedures.

\section{Flow cytometric determination of cellular DNA content}

Cells were seeded in cell culture medium supplemented with $10 \%$ FCS. TNF, insulin and Z-VAD-fmk were added as indicated, and incubated for $8 \mathrm{~h}$. Detached and adherent cells were collected (30 min incubation with $0.02 \%$ EDTA), and washed twice in PBS containing $2 \%$ FCS $\left(4^{\circ} \mathrm{C}\right)$. Cell number was adjusted to 2 Mio per $\mathrm{ml}$. Three $\mathrm{ml}$ icecold ethanol was added to $1 \mathrm{ml}$ cell suspension and the suspension was vortexed. The cells were stored overnight at $4{ }^{\circ} \mathrm{C}$, and were washed twice with PBS and stained for $3 \mathrm{~h}$ at $4{ }^{\circ} \mathrm{C}$ with $1 \mathrm{ml} \mathrm{PI}$-Solution (50 $\mu \mathrm{g} / \mathrm{ml}$ propidium iodide, $3.8 \mathrm{mM}$ sodium citrate, $50 \mu \mathrm{g} / \mathrm{ml}$ ). The samples were analyzed in an EPICS XL-MCL (Coulter Immunotech Diagnostics).

\section{Acknowledgements}

This work was supported by the Bundesministerium für Bildung, Wissenschaft, Forschung und Technologie, Germany (FKZ 0316500C, Projekt B.3.10.E).

\section{References}

1. Ashkenazi A and Dixit VM (1999) Apoptosis control by death and decoy receptors. Curr. Opin. Cell Biol. 11:25-26

2. Wajant $\mathrm{H}$, Pfeffer K, Pfizenmaier K and Scheurich $P$ (1998) Tumor necrosis factors in 1998. Cytokine Growth Factor Rev. 9: 297-302

3. Hotamisligil GS (1999) The role of TNF alpha and TNF receptors in obesity and insulin resistance. J. Intern. Med. 245: 621-625

4. Hotamisligil GS, Murray DL, Choy LN and Spiegelman BM (1994) Tumor necrosis factor $\alpha$ inhibits signaling from the insulin receptor. Proc. Nat. Acad. Sci. USA 91: 4854-4858

5. Kanety H, Feinstein R, Papa MZ, Hemi R and Karasik A (1995) Tumor necrosis factor $\alpha$-induced phosphorylation of insulin receptor substrate-1 (IRS-1). Possible mechanism for suppression of insulin stimulated tyrosine phosphorylation of IRS-1. J. Biol. Chem. 270: 23780-23784 
6. Uysal KT, Wiesbrock SM, Marino MW and Hotamisligil GS (1997)Protection from obesity induced insulin resistance in mice lacking TNF- $\alpha$ function. Nature 389: 610-614

7. Stephens JM and Pekala PH (1991) Transcriptional repression of the GLUT4 and C/EBP genes in 3T3-L1 adipocytes by tumor necrosis factor-alpha. J. Biol. Chem. 266: 21839-21845

8. Hotamisligil GS, Peraldi P, Budavari A, Ellis R, White MF and Spiegelman BM (1996) IRS-1-mediated inhibition of insulin receptor tyrosine kinase activity in TNF- $\alpha$ and obesity induced insulin resistance. Science 271: 665-668

9. Paz K, Hemi R, LeRoith DL, Karasik A, Elhanany E, Kanety Hand Zick Y (1997) A molecular basis for insulin resistance. J. Biol. Chem. 272: 29911-29918

10. Feinstein R, Kanety H, Papa MZ, Lunenfeld B and Karasik A (1993) Tumor necrosis factor- $\alpha$ suppresses insulin-induced tyrosine phosphorylation of insulin receptor and its substrates. J. Biol. Chem. 268: 26055-26058

11. Hotamisligil GS, Shargil NS and Spiegelman BM (1993) Adipose expression of tumor necrosis factor- $\alpha$ : direct role in obesity linked insulin resistance. Science 259: $87-90$

12. Storz P, Döppler H, Wernig A, Pfizenmaier K and Müller G (1998) TNF inhibits insulin induced STAT5 activation in differentiated mouse muscle cells pmi28. FEBS Lett. 440: 41-45

13. Storz P, Döppler H, Wernig A, Pfizenmaier K and Müller G (1999a) Cross-talk mechanisms in the development of insulin resistance of skeletal muscle cells Palmitate rather than tumour necrosis factor inhibits insulin-dependent protein kinase B (PKB)/Akt stimulation and glucose uptake. Eur. J. Biochem. 266: 17-25

14. Chen J, Sadowski HB, Kohanski RA and Wang L-H (1997) Stat5 is a physiological substrate of the insulin receptor. Proc. Natl. Acad. Sci. U.S.A. 94: 2295-2300

15. Storz $P$, Döppler H, Pfizenmaier $K$ and Müller $G$ (1999b) Insulin selectively activates STAT5b, but not STAT5a via a JAK2-independent signalling pathway in Kym-1 rhabdomyosarcoma cells. FEBS Lett. 464: 159-163

16. Sharma PM, Egawa K, Gustafson TA, Martin JL and Olefsky JM (1997) Adenovirus-mediated overexpression of IRS-1 interacting domains abolishes insulin-stimulated mitogenesis without affecting glucose transport in 3T3-L1 adipocytes. Mol. Cell. Biol. 17: 7386-7397

17. Onishi M, Nosaka T, Misawa K, Mui AL, Gorman D, McMahon M, Miyajima A and Kitamura T (1998) Identification and characterization of a constitutively active STAT5 mutant that promotes cell proliferation. Mol. Cell. Biol. 18: 3871-3879

18. Welte T, Leitenberg D, Dittel BN, al-Ramadi BK, Chin YE, Janeway Jr CA, Bothwell ALM, Bottomly K and Fu XY (1999) STAT5 interaction with the T cell receptor complex and stimulation of $T$ cell proliferation. Science 283: 222-225

19. Liu RY, Fan C, Garcia R, Jove R and Zuckerman KS (1999) Constitutive activation of the Jak2/STAT5 signal transduction pathway correlates with growth factor independence of megakaryocytic leukemic cell lines. Blood 93: 23692379

20. Yenush L, Zanella C, Uchida T, Bernal D and White MF (1998) The pleckstrin homology and phosphotyrosine binding domains of insulin receptor substrate 1 mediate inhibition of apoptosis by insulin. Mol. Cell. Biol. 18: 6784-6794

21. Rui H, Xu J, Metha S, Fang H, Williams J, Dong F and Grimley PM (1998) Activation of the Jak2-Stat5 signaling pathway in Nb2 lymphoma cells by an antiapoptotic agent, aurintricarboxylic acid. J. Biol. Chem. 273: 28-32

22. Bao H, Jacobs-Helber SM, Lawson AE, Penta K, Wickrema A and Sawyer ST (1999) Protein kinase B (c-Akt), phosphatidylinositol 3-kinase, and STAT5 are activated by erythropoietin (EPO) in HCD57 erythroid cells but are constitutively active in an EPO-independent, apoptosis-resistant subclone (HCD57-SRE1 cells). Blood 93: 3757-3773

23. White MF and Kahn CR (1994) The insulin signaling system. J. Biol. Chem. 269: 1-4

24. Navarro $P$, Valverde AM, Benito M and Lorenzo M (1998) Insulin/IGF-1 rescues immortalized brown adipocytes from apoptosis down-regulating $\mathrm{Bcl}-\mathrm{xS}$ expression, in a PI 3-kinase- and map kinase-dependent manner. Exp. Cell. Res. 243: 213-221

25. Ito T, Sasaki Y and Wands JR (1996) Overexpression of human insulin receptor substrate 1 induces cellular transformation with activation of mitogen-activated protein kinases. Mol. Cell. Biol. 16: 943-951

26. Franke TF, Kaplan DR and Cantley LC (1997) PI3K: Downstream AKTion blocks apoptosis. Cell 88: $435-437$

27. Khwaja A (1999) Akt is more than just a Bad kinase. Nature 401: $33-34$

28. Blakesley VA, Scrimgeour A, Esposito D and Le Roith D (1996) Signaling via the insulin-like growth factor-I receptor: does it differ from insulin receptor signaling? Cytokine Growth Factor Rev. 2: 153-159
29. Grell M, Zimmermann G, Hülser D, Pfizenmaier K and Scheurich P (1994) TNF receptors TR60 and TR80 can mediate apoptosis via induction of distinct signal pathways. J. Immunol. 153: 1963-1972

30. Bourteele S, Hausser A, Döppler H, Horn-Müller J, Röpke C, Schwarzmann G, Pfizenmaier K and Müller G (1998) Tumor Necrosis Factor induces ceramide oscillations and negatively controls sphingolipid synthases by caspases in apoptotic Kym-1 cells. J. Biol. Chem. 273: 31245-31251

31. El-Badry OM, Minniti C, Kohn EC, Houghton PJ, Daughaday WH and Helman LJ (1990) Insulin-like growth factor II acts as an autocrine growth factor and motility factor in human rhabdomyosarcoma tumors. Cell Growth Differ. 7: 325-331

32. Parrizas M, Gazit A, Levitzki A, Wertheimer E and LeRoith D (1997) Specific inhibition of insulin-like growth factor-1 and insulin receptor tyrosine kinase activity and biological function by tyrphostins. Endocrinology 131: 1427-1433

33. Baltensperger K, Lewis RE, Woon CW, Vissavajjhala P, Ross AH and Czech MP (1992) Catalysis of serine and tyrosine autophosphorylation by the human insulin receptor. Proc. Natl. Acad. Sci. U.S.A. 89: 7885-7889

34. Cohen GM (1997) Caspases: the executioners of apoptosis. Biochem. J. 326: 1-16

35. Grell M, Wajant H, Zimmermann $G$ and Scheurich $P$ (1998) The type 1 receptor (CD120a) is the high-affinity receptor for soluble tumor necrosis factor. Proc. Natl. Acad. Sci. U.S.A. 95: 570-575

36. Grell M, Zimmermann G, Gottfried E, Chen C-M, Grunwald U, Huang DC, WuLee YH, Durkop H, Engelmann H, Scheurich P, Wajant H and Strasser A (1999) Induction of cell death by tumour necrosis factor (TNF) receptor 2, CD40 and CD30: a role for TNF-R1 activation by endogenous membrane-anchored TNF. EMBO J. 18: 3034-3043

37. Grimley PM, Dong F and Rui H (1999) Stat5a and Stat5b: fraternal twins of signal transduction and transcriptional activation. Cytokine Growth Factor Rev. 10: $131-157$

38. Brunet A, RouxD, Lenormand P, Dowd S, Keyse S and PouysségurJ (1999) Nuclear translocation of p42/p44 mitogen-activated protein kinase is required for growth factor-induced gene expression and cell cycle entry. EMBO J. 18: 664-674

39. Xia Z, Dickens M, Raingeaud J, Davis RJ and Greenberg ME (1995) Opposing effects of ERK and JNK-p38 MAP kinases on apoptosis. Science 270: $1326-$ 1331

40. Darnell Jr JE (1997) STATs and gene regulation. Science 277: 1630 - 1635

41. Moriggl R, Topham DJ, Teglund S, SexI V, McKay C, Wang D, Hoffmeyer A, van Deursen J, Sangster MY, Bunting KD, Grosveld GC and Ihle JN (1999) STAT5 is required for IL-2-induced cell cycle progression of peripheral T cells. Immunity 10: $249-259$

42. Stöcklin E, Wissler M, Gouilleux F and Groner B (1996) Functional interactions between Stat5 and the glucocorticoid receptor. Nature 383: 726-728

43. Ceresa BP, Horvath CM and Pessin JE (1997) Signal transducer and activator of transcription-3 serine phosphorylation by insulin is mediated by a Ras/Raf/MEKdependent pathway. Endocrinology 138: 4131-4137

44. Pircher TJ, Petersen H, Gustafsson JA and Haldosen LA (1999) Extracellular signal-regulated kinase (ERK) interacts with signal transducer and activator of transcription (STAT) 5a. Mol. Endocrinol. 13: 555-565

45. Gardner AM and Johnson GL (1996) Fibroblast growth factor-2 suppression of tumor necrosis factor alpha-mediated apoptosis requires Ras and the activation of mitogen-activated protein kinase. J. Biol. Chem. 271: 14560-14566

46. Simon HU, Yousefi S, Dibbert B, Levi-Schaffer F and Blaser K (1997) Antiapoptotic signals of granulocyte-macrophage colony-stimulating factor are transduced via Jak2 tyrosine kinase in eosinophils. Eur. J. Immunol. 27: $3536-$ 3539

47. Miele C, Caruso M, Calleja V, Auricchio R, Oriente F, Formisano P, Condorelli G, Cafieri A, Sawka-VerhelleD, Van ObberghenEandBeguinot $F(1999)$ Differential role of insulin receptor substrate (IRS)-1 and IRS-2 in L6 skeletal muscle cells expressing the Arg1152 $\rightarrow$ Gln insulin receptor. J. Biol. Chem. 274: 3094-3102

48. Müller G, Storz P, Bourteele S, Döppler H, PfizenmaierK, MischakH, Phillip A, Kaiser Cand Kolch W (1998) Regulation of C-Raf-1 kinase by TNFviaits second messenger ceramide and cross-talk with mitogenic signalling. EMBO J. 17:732-742

49. Zhou H, Summers SA, Birnbaum MJ and Pitman RN (1998) Inhibition of Akt kinase by cell-permeable ceramide and its implications for ceramide induced apoptosis. J. Biol. Chem. 273: 16568-16575

50. Kuroki J, Hirokawa M, Kitabayashi A, Lee M, Horiuchi T, Kawabata Y and Miura AB (1996) Cell-permeable ceramide inhibits the growth of B lymphoma Raji cells lacking TNF-alpha-receptors by inducing G0/G1 arrest but not apoptosis: a new model for dissecting cell-cycle arrest and apoptosis. Leukemia 10: 950-958 
51. Kohn AD, Kovacina KS and Roth RA (1995) Insulin stimulates the kinase activity of RAC-PK, a pleckstrin homology domain containing ser/thr kinase. EMBOJ.14: 4288-4295

52. Heidenreich KA and Kummer $\mathrm{JL}$ (1996) Inhibition of p38 mitogen-activated protein kinase by insulin in cultured fetal neurons. J. Biol. Chem. 271: 9891 9894

53. Eldar-Finkelman H and Krebs EG (1997) Phosphorylation of insulin receptor substrate 1 by glycogen synthase kinase 3 impairs insulin action. Proc. Nat. Acad. Sci. U.S.A. 94: 9660-9664
54. Kroder G, Bossenmaier B, Kellerer M, Capp E, Stoyanov B, Muhlhofer A, Berti L, Horikoshi H, Ullrich A and Häring H (1996) Tumor necrosis factor-alpha- and hyperglycemia-induced insulin resistance. Evidence for different mechanisms and different effects on insulin signaling. J.Clin. Invest. 97: 1471-1477 